\title{
Die filioque: Ekumeniese speelbal of reformatories teologiese noodsaaklikheid
}

\section{J Otto \& J H Koekemoer \\ Universileit van Pretoria}

\begin{abstract}
The filioque

The current debate within the ecumenical movement about the filioque has its origin in the Greek Orthodox church's demand that the NicencoConstantinopolitanum be accepted in its original form. Only if a universally acceptable symbol is found, can there be any hope of progress in the movement to unity. The choice put by the ecumenical movement is between unity and filioque. It is the contention in this article that this choice is a false one. From an oveniew of the most important historical aspects of the problem, the reader is confronted by the problem. This is followed by a discussion of the points of view of the orthodox church, the ecumenical movement and Protestant theology. This discussion shows the impasse which the choice between filioque and unity creates. A discussion of the concept of models, as instrument within theological language, has as goal to show that this impasse can be solved. If theological language uses models in its discussions, any talk about filioque will be open to more than one interpretation. Filioque can still be used to say something about the Trinity, even in the ecumenical movement.
\end{abstract}

\section{INLEIDING}

Credimus in Spiritum Sanctum qui a Patre Filioque procedit. So lui die Latynse weergawe van die betrokke artikel in die Niceno-Constantinopolitanum wat aanleiding gegee het tot die filioque kontrovers. Hierdie is 'n strydpunt wat sy oorsprong het in 'n byvoeging wat die Roomse Weste tot die geloofsbelydenis na aanleiding van sy teologiese denke gemaak het. Die vraagstuk het vandag met die momentum wat die ekumeniese beweging gekry het, opnuut op die voorgrond getree. Om die probleem te kan verstaan, sal daar eers 'n kort oorsig oor die belangrikste historiese gegewens gegee moet word. Die eerste ontwikkeling in dogmatiese denke sal aangedui word, waarna 'n oorsig oor die standpunt, wat tans deur

- Ingedien en aanvaar as deel van die vereistes vir die MDiv-graad, Fakulteit Teologie (Afd A), Universiteit van Pretoria, onder leiding van prof dr J H Koekemoer. 
deur die ekumeniese beweging en die Ortodokse Ooste gehuldig word, sal volg. Daarna sal die Reformatore se standpunt gestel word, voordat by ' $n$ beoordeling van die filioque gekom kan word. In dié beoordeling sal die noodwendigheid van die filioque teenoor 'n standpunt wat van die term 'n blote speelbal wil maak, gestel word.

Op grond van die groot verskil wat daar tussen Oos en Wes oor die filioque bestaan, word daar soms afgelei dat daar absoluut oor alles verskil word. Dit is nie waar nie. Filioque verbeeld verskillende maniere van teologie bedryf. Indien die liturgieë van Oos en Wes met mekaar vergelyk sou word, sou met die uitsondering van taalverskille, kwalik tussen die twee onderskei kon word (Fahey 1979:15). Dieselfde denke word gehandhaaf rondom die inspirasie van die Skrif, die teenwoordigheid van die Gees in die sakramente, die gee van gawes aan die gelowiges en talle ander aspekte - 'n belangrike punt om in gedagte te hou. Die verskillende raakpunte kan altyd omgebou word tot groter konsensus, terwyl filioque die twee kante reg teenoor mekaar stel. Oos en Wes se pneumatologie verskil nie werklik veel van mekaar nie. Die debat is eerder toegespits op die leer aangaande die Triniteit, of Triadologie soos die Ooste na die Triniteitsleer verwys (Fahey 1979:19).

Een van die redes vir die ontstaan van die verskil tussen die Ortodokse Ooste en die Rooms Katolieke se standpunte, is die verskil in taal. Die Ooste het Grieks as kerktaal behou vir die bedryf van teologie, terwyl Latyn die oorwig in die Weste gekry het. Vir die Ooste was dit maklik om naby aan Bybelse formulerings te bly (Fahey 1979:19). Direkte Skrifuitsprake, asook dieselfde woorde, is in die formulering van 'n standpunt gebruik. Die Weste moes vertaal en reeds hier het daar onvermydelike verskille na vore begin tree. Vertaling gee ook groter vryheid en terme kon uit die filosofiese denke oorgeneem word in 'n poging om 'n teologiese probleem hok te slaan. Die debatte wat Oos en Wes gevoer het, was ook elk in 'n eie konteks. So byvoorbeeld was Augustinus se werk eers in die veertiende eeu in Grieks vertaal, terwyl hy self nooit Grieks baas geraak het nie, wat beteken het dat die groot werk van die drie Kappadosiërs vir hom ontoeganklik was (Stylianopoulos 1979:28).

\section{HISTORIESE AGTERGROND}

Die Niceno-Constantinopolitanum is die enigste belydenis wat deur die hele Kerk van die antieke tyd tydens 'n konsilie goedgekeur is, wat beteken dat dit 'n besondere plek in enige ekumeniese gesprek sal inneem. Selfs die Apostolicum, wat eers teen die agste eeu gefinaliseer is, is later geformuleer en nooit deur 'n volle konsilie behandel nie, al kan van die artikels tot die vierde eeu terug gedateer word (Heron 1987:843). Die eerste elemente van die Niceno-Constantinopolitanum is 
reeds te bespeur by die ekumeniese konsilie van 325 alhoewel dit eers in 381 te Konstantinopel finaal aanvaar word (Heron 1987:843). In hierdie teks is daar inderdaad geen sprake van die filioque nie. Die oorspronklike teks maak slegs melding dat die Gees van die Vader uitgaan. Met verloop van tyd egter, in antwoord op ketterye, het daar in die Latynse Weste denke na vore getree wat die filioque sterk ondersteun.

Voordat die eerste woorde van enige belydenis op papier neergepen is, was daar sprake van 'n sekere ontwikkeling. Sover dit teologiese denke betref, 'n ontwikkeling wat uit noodsaak gebore is. Denke oor die Triniteit (as die besondere konteks waarbinne die filioque bespreek word) is gou as onontbeerlik aangedui. Die Jode het die Christene van politeïsme beskuldig, onderwyl die Romeine daarteenoor nie kon verstaan hoe hierdie groep mense weier om die Keiser te aanbid, terwyl hulle 'n man van Nasaret as God aanbid nie. Teenoor die twee groepe moes die Christene hulself regverdig. Aan die een kant moes daar klem gelê word op die Godheid van Christus en logies volg daaruit die Godheid van die Gees. Aan die ander kant moes daar sterk klem gelê word op die eenheid van die God wat aanbid word. Dit is tussen die pole van Drie-in-Een en Een-in-Drie dat die denke van die vroeë kerk plaasgevind het. In hierdie denke is dit ook belangrik dat die verband tussen die Drie-in-Een duidelik uitgestip sal word. Die probleem is egter dat daar nie direkte sitate uit die Skrif aangehaal kan word om woordeliks die standpunte van die vroeë Kerk te regverdig nie. Denke oor die Triniteit is die uitvloeisel van Skrifinterpretasie.

Die eerste spore van filioque word in die vyfde eeu in liturgiese gebruik by die Spanjaarde gevind. Dit verskyn in die kanon van die konsilie van Toledo (446-447) en word onder andere in die konsilie van Fruili (796) deur Paulinius van Aquileia verdedig (Ritschl 1979:6). Alhoewel Johannes van Damaskus in die agste eeu die Ooste se standpunt begin stel, is dit eers met die werk van Photius in 867 dat die Griekssprekende deel van die kerk sterk standpunt teen die filioque inneem. Charlemagne probeer om in die agste eeu die invoeging van die filioque deur te voer, maar Leo III (al stem hy saam met die teologie van die filioque) verhoed dat dit gedoen word. Die Westerse kerk swig egter voor volgehoue druk en in 1014 (veertig jaar voor die finale skeur tussen Oos en Wes) keur Benedictus VIII finaal die toevoeging tot die belydenis goed (Heron 1987:844).

Die twee vaders van die twee Triadologieë of Triniteitslere, is Origenes in die Griekssprekende Ooste en Augustinus in die Latynssprekende Weste. Dié twee teoloë vorm die basis waarop verdere geslagte voortbou. Origenes het die triadologie verduidelik deur gebruik te maak van die term hupostasis. Dit is 'n filosofiese term, maar tog ook nie sonder Skrifbasis nie, aangesien dit in Heb 1:3 vir die 
persoon van Christus gebruik word. Hierdie hupostasis was "n objektiewe realiteit in staat tot handeling' (Bray 1983:105). Sover Origenes kon sien, was daar drie sulke realiteite wat deur die Christene aanbid is en hy plaas die drie hupostasis in 'n hiërargiese volgorde. Na die dood van Origenes sou dié denké die basis vir verdere teologiese denke in die Ooste wees. Vir solank die Platoniese agtergrond waarbinne dié teologie vorm aangeneem het, gehandhaaf is, het dit goed gegaan. Arius was egter in die logika van Aristoteles onderlè. Hy stel dit dat 'n verskil in naam, 'n verskil in wese aandui en dit beteken dat slegs die Vader God is; Seun en Gees is skepsels. Nicea verwerp egter die kettery in 325 toe bevestig word dat die Seun van dieselfde wese as God die Vader is (homoousios).

Die drie Kappadosiërs het die denke van Origenes tot 'n mooi sisteem afgerond. Basilius neem die eerste stappe tot sisteemdenke deur die drie hupostasis nader te omskryf as: Die wyses van bestaan binne die enkele Goddelike wese. In dié wese is Vader, Seun en Gees steeds hiërargies gerangskik en word aan elkeen 'n ander wyse van bestaan toegeken wat uniek is aan daardie hupostasis. Gregorius Epifanus en Gregorius van Nyssa het dié sisteem op so wyse afgerond dat die filioque nooit werklik ruimte kon hé nie, aangesien dit inbreuk sou maak op die eienskappe van die hupostasis van die Vader. Gregorius van Nyssa se formulering verwys na Vader, Seun en Gees as: Die ongegenereerde, die gegenereerde en die een wat uitgaan (Bray 1983:109). 'n Tweese fase in die denke van die Ooste was om hierdie eienskappe te abstraheer na wyses van bestaan naamlik ongegenereerdheid, gegenereerdheid en uitgang (Bray 1983:110). Hierdeur het die drie Kappadosiërs die drie synswyses kriteria gemaak waaraan die triadologie gemeet moet word. Dit het dan die eienskappe geword wat as onvervreembaar aan elk van die drie hupostasis van God toegeken is. Dit wil sê die verhoudings tussen die drie Persone is verobjektiveer deur dié verhoudings eienskappe van Vader, Seun en Gees te maak.

Die Latynse tradisie begin met Tertulianus wat kies vir die term substantia om die Eenheid (hupostasis) van God aan te dui en die term persona om die drie persone aan te dui. Die beswaar hierteen was dat dié gebruik die wese van God terugvoer na ' $n$ onpersoonlike essensie (Bray 1983:112). Hoe dit ookal mag wees, dit is dadelik duidelik dat 'n teologie wat langs hierdie lyn ontwikkel gaan word, totaal anders daar gaan uitsien as die Griekse vertrekpunt. Augustinus verteenwoordig 'n volgende stap in die Weste se denke; hy verkies die term essentia in die plek van substantia, wat ooreenstem met die Griekse term vir wese (ousia). Hy aanvaar die term persona, al voel hy nie totaal gelukkig met die keuse nie (Bray 1983:114). Die eerste gevolg van diê keuse van Augustinus is dat die verwarring wat Tertullianus met die vertaal van hupostasis met substantia geskep het, nou uit die weg geruim is. Augustinus stel dat die drie persone synswyses in die een God is. Anders as die 
Kappadosiërs wat twee vlakke onderskei, naamlik syn en eksistensie, is hulle vir Augustinus een. Dit beteken nie dat die Vader, Seun en Gees verskillende name vir dieselfde God is nie, die name is aanduiding van verskillende verhoudinge binne die een essensie. Die teologie wat dien as basis vir die filioque verskyn die eerste keer in die opvattinge van Augustinus soos vervat in 'de trinitate' in 419 . So vroeg as 447 sien ons dat die filioque gehandhaaf word as deel van die Katolieke leer teenoor die leer van die Arianisme. Die filioque vorm so deel van die Weste se denke dat die Symbolum Quiqumque wat ongeveer $500 \mathrm{n} \mathrm{C} \mathrm{opgestel} \mathrm{is} \mathrm{ook} \mathrm{die} \mathrm{woord} \mathrm{filioque} \mathrm{be-}$ vat sonder diepere teologiese regverdiging vir dié keuse.

Bray (1983:118) onderskei vier fases in die ontwikkeling van die filioque vraagstuk. Indien in ag geneem word hoe gou ketterse leer hanteer is en standpunt teen ketters ingeneem is, moet erken word dat dit vir die kerk uitsonderlik lank geneem het om die probleem rondom die filioque te hanteer. Vir die doeleindes van dié gesprek kan slegs kennis geneem word van die vier fases waarna Bray verwys:

* die probleem word nie herken nie;

* die probleem word herken maar nie verstaan nie;

* die probleem word verstaan, maar word nie as fundamenteel gesien nie; en

* die probleem word herken, word as fundamenteel gesien maar nie ten volle in die konteks van dogmatiek en spiritualiteit verduidelik nie (Bray 1983:118).

Elk van hierdie fases het etlike jare geduur. Nieteenstaande hierdie groot misverstand tussen Ortodokse Ooste en die Rooms-Katolieke kerk, tree beide partye met groot beslistheid op.

Die filioque word in 1014 amptelik in die Rooms Katolieke kerk by die NicenoConstantinopolitanum gevoeg. Veertig jaar later ekskommunikeer Pous en Patriarg mekaar en beskuldig die een die ander daarvan dat 'n ketterse leer aangehang word. Oos en Wes skeur, 'n skeuring wat tot vandag toe geld. Hierdie skeuring was nie absoluut nie, hiervan is die konsilies te Florence 'n tekenende voorbeeld, aangesien daar afgevaardigdes van die Ortodokse Ooste teenwoordig was. In die tyd na die skeuring het daar sporadies teoloë na vore gekom wat die saak opnuut beredeneer het. Een so 'n teoloog was Anselmus. Sy besondere bydrae lê daarin dat hy die basis vir Skrifbewyse uitgebrei het. Die tekste van Johannes 14:26 en 15:26 is tradisioneel gebruik deur die Ooste om die filioque te verwerp. Anselmus brei egter die eksegese uit na die geheel van Johannes 14-17 asook tekste soos Matteus 11:27. Hierdie belangrike insig sou later deur die Reformatore uitgebrei word. Anselmus het in ieder geval aangedui dat die filioque nie by Johannes 15:26 staan of val nie. 
Ritschl (1979:3) stel dat die filioque bygevoeg is om iets te sê van die innerlike verhouding van die Triniteit. Volgens hom sou dit 'n totale misverstand wees om die filioque anders te verstaan. Alhoewel dit waar is dat die filioque om dié rede by die belydenis gevoeg is, is dit nie vandag meer die rede vir die handhawing van die filioque nie. Dit maak nie die standpunt minder geldig nie, dit kom ook nie neer op 'n wanvoorstelling van die saak nie, aangesien hier meer as net geskiedenis ter sprake is, dit gaan om 'n totale manier van teologie bedryf. Maximus, alhoewel hy nie bekend was vir sy trinitariese teologie nie (Berthold 1985:113), het tog sy teologie trinitaries (of moet ons sê triadologies) ingerig. Hy was 'n groot ondersteuner van die Niceno-Constantinopolitanum (Berthold 1985:113). Juis omdat hy vasgehou het aan die gedagte van die Drie-Eenheid, het hy die filioque meer positief waardeer. Sy interpretasie van die filioque was dat die Gees van die Vader deur die Seun uitgaan (Berthold 1985:113). Alhoewel hy vashou aan die gedagte dat die Vader die hoofbron van die Gees is, wil hy tog ook aandui dat die Seun en die Gees nie van mekaar geskei kan word nie. Die Seun is betrokke as Middelaar. Hierdie onderskeid geld nie net die ekonomiese nie, maar ook die immanente Triniteit (Berthold 1985:114). Dit is duidelik dat hierdie standpunt van Maximus per filium bedoel en nie filioque nie. Die vraag kan tereg gestel word waarom dit moontlik is dat hy so 'n positiewe waardering vir die filioque kan hê? Die oplossing lê daarin dat Maximus oortuig was dat daar 'n verwarring rondom taalgebruik was, eerder as 'n groot teologiese verskil (Berthold 1985:115). Volgens hom gebruik die Latyn twee woorde (causa en principium) om een Griekse woord (aitia) te vertaal. Hierdie verwarrende taalgebruik (volgens die Grieke) het tot gevolg dat dit kan lyk asof die filioque aandui dat die Gees twee bronne van oorsprong het, en dit klink na 'n ketterse uitlating. Maximus se positiewe waardering van die filioque is getemper deur die Oosterse denke rondom die oorsprong van die Gees aangesien hy raakgesien het dat die Pneumatologie en die leer aangaande die triniteit ter sprake is. Sy beoordeling was meer positief as dié van Photius wat die Ortodokse denke deur die eeue sou bepaal.

Photius het met sy beoordeling van die filioque die Ortodokse standpunt geradikaliseer deur die uitgaan van die Gees slegs vanaf die Vader te beskryf (Fahey 1979:15). Hy stel in 866 dat die filioque die alleenheerskappy van die Vader vernietig. Sy verwerping van die filioque was totaal gewees. Hy baseer sy verwerping op drie aannames naamlik, die eie woorde van Jesus, die besluite van die Algemene Konsilies en die geskrifte van die vadere (Stratoudaki-White 1983:248). Volgens hom word die Gees gestuur van dit wat Syne (Jesus) is, dit wil sê van die Vader. Verder het nie een van die Algemene Konsilies die invoeging van die filioque goedgekeur nie, en daar is 'n groot hoeveelheid van geskrifte van die vroeë vadere wat 
nie die filioque aanvaar nie. Dié wat wel met die filioque saamstem, kan nie opgeroep word om hulle standpunt te verdedig nie en moet derhalwe volgens hom vergewe word en met rus gelaat word (Stratoudaki-White 1983:248). Hy stel ook dat dit uit die Weste se standpunt nie al te duidelik is of die uitgaan van die Vader dieselfde is as dié van die Seun nie (Bray 1983:123). Indien wel, los die hupostasis van die Vader op in dié van die Seun. Effektief skei dit God in twee. Photius se invoeging dat die Gees net van die Vader uitgaan, is 'n standpunt wat stilswyend vandag nog deur die Ortodokse kerk gehandhaaf word. Selfs al erken hy dat die Skrif van die Heilige Gees praat as die Gees van Christus, ontken hy dat daar enige sprake van die oorsprong van die Gees in Christus kan wees. Photius se radikale reaksie maak dat hy nie die positiewe uitdaging van die filioque, naamlik die vraag na die verhouding tussen Gees en Christus, kan hanteer nie.

Augustinus het in sy hantering van die stryd teen die dwalinge van Arius, wat die Seun as 'n geskape wese gesien het, die leer van die Triniteit geformuleer om die denke teen te werk en die Goddelikheid van Jesus bo alle twyfel te stel. Alhoewel Augustinus nie die filioque gebruik nie, baan sy denke die weg vir die filioque, veral soos dit ook in die Symbolum Quicum-qui na vore kom (Clapsis 1982:128). Daar was geen doelbewuste verdraaing van die teologie nie, net 'n ernstige poging om Donatus en Arius se kettery teen te werk. Die feit dat die Weste Latyn as taal van die teologie, en die Ooste Grieks gebruik het, het meegewerk om die misverstand te vererger. Die stryd wat die Weste teen kettery moes voer, het tot gevolg gehad dat daar sterk gesteun is op die teologie van Augustinus. So aanvaar die Konsilie van Toledo (589) die filioque as antwoord op die Arianisme (Clapsis 1982:129).

\section{ORTODOKSE STANDPUNT}

Die Ortodokse kerk noem homself soms die kerk van die Sewe Konsilies en verwys dan na die sewe Algemene Konsilies wat deur die hele Kerk onderskryf is. Die belang van hierdie konsilies word duidelik uit die Ortodokse Ooste se hantering van die filioque. Daar word van die Weste gevra om standpunt in te neem oor die Triniteit, soos uiteengesit in die eerste konsilies (Stylianopoulos 1979:30). Die oorspronklike formulering, soos vervat in die 381-vorm van die Niceno- Constantinopolitanum, moet as die normatiewe formulering aanvaar word (Stylianopoulos 1991:275). As riglyn hiervoor kan die Klingenthal Memorandum (wat deur Vischer verwerk is en in boekvorm uitgegee is as 'Spirit of God, Spirit of Christ') gebruik word. 
Volgens die Ooste kom die filioque neer op df die skep van twee bronne, $\partial f$ ' $n$ vervaging van die onderskeid tussen Vader en Seun (Heron 1983:93). Die byvoeging van die filioque is 'n eensydige, onregmatige byvoeging en wel om drie redes. In die eerste instansie is dit onskriftuurlik, tweedens is dit nie in harmonie met kerklike tradisie nie en derdens is dit dogmaties nie waar nie en hou daarom gevaarlike gevolge in (Ritschl 1979:4). Hieruit is dit duidelik dat daar etlike redes genoem kan word.

Volgens sommiges in die Ortodokse Ooste is die filioque die én dogmatiese rede vir die skeiding tussen Oos en Wes (Bray 1983:95) terwyl die Rooms Katolieke kerk die filioque as van minder belang beskou. Daar is persone in die Rooms Katolieke kerk wat selfs voel dat dit nie ketters sou wees om die filioque uit te laat nie, maar dat dit beter is om dit wel te behou. Emmanuel Clapsis (1982:127) gee in sy artikel die Ortodokse standpunt duidelik weer. Die filioque gee uitdrukking aan die verhouding van die Gees tot die Seun, maar ook tot die Vader. Dit moet duidelik gestel word dat die liturgiese aspek baie hoog deur die Ortodokse Ooste aangeslaan word. Dit gaan primêr oor die God wat in die geskiedenis optree en deur die mens aanbid word. Spreke oor God Drie-Enig is nie filosofiese teorie nie, maar spreke oor die lewende God van die geskiedenis (Clapsis 1982:127). Hieruit is dit duidelik dat 'n lewende verhouding met God 'n belangrike rol gaan speel wat as verhouding in die liturgie tot uiting kom. Hierdie fokus kan egter oordrewe beklemtoon word, soos blyk uit die mistiese siening wat die Ortodokse kerk handhaaf rondom die erediens.

Die filioque word as 'n onbybelse byvoeging gesien wat tog teologiese invloed het. Soos reeds gestel, is Johannes 15:26 die enigste Skrifbewys wat die Ooste aanvaar. By hierdie teksvers staan of val die uitgaan van die Gees volgens die Ooste. In hierdie Skrifgedeelte is daar slegs sprake van die Vader wat die Gees stuur. Die grootste verskil tussen die Ooste en die Weste is blykbaar gesetel in die benadering wat ieder volg. Die Weste sien eers die Een God voor die drie persone gesien word, terwyl die Ooste God eers ken as drie persone en dan as Een God (Clapsis 1982:127). Indien verder in ag geneem word dat die Heilige Gees betrokke is by die skepping, die geboorte en die doop van Jesus, word dit duidelik dat die toepassing van die leer in die Weste ten aansien van die filioque bevraagteken kan word op grond van die toereikendheid daarvan (Clapsis 1982:130; Every 1979:48). Augustinus - en na hom die hele Westerse teologie - het dit wat eie is aan elke persoon in die Drie-eenheid verwar met dit wat gemeenskaplik is. Volgens die Ooste is slegs die Vader die bron en oorsprong. Alhoewel Augustinus stel dat die Gees primêr van die Vader uitgaan, is dit vir die Ooste nie aanvaarbaar nie. Dit tas volgens hulle die monargie van die Vader aan (Clapsis 1982:133) en verwar die 
eienskappe van die Drie-eenheid onderling. Die Ortodokse kerk wil nie sien dat ons die een Wil van God verwar met die drie Persone, of met hulle onderlinge verhoudings nie. Die drie Persone is verenig maar tog nie dieselfde nie, terwyl die filioque volgens Ortodokse denke die Gees ondergeskik aan die Seun stel en twee bronne van Goddelikheid daarstel. Indien die filioque ontken word, bring dit die verhouding van die Gees met die Seun weer in gedrang. Hier sou die Oosterse kerk tog 'n eenheid van werke voorstel, gebaseer op die ekonomiese Triniteit (Clapsis 1982:134).

Volgens die Ooste is daar 'n groot verskil tussen immanente- en ekonomiese Triniteit. Die filioque moet van die Niceno-Constantinopolitanum verwyder word. Dan kan daar gesprek gevoer word oor hoe die teologie waarbinne die filioque geld, tog in 'n ekumeniese opset kan geld (Clapsis 1982:134). In hulle poging om van Christomonisme te ontsnap, maak hulie hulself egter skuldig aan spekulasie oor dit wat God nie openbaar het nie. Hier word verwys na die groot onderskeid tussen immanente- en ekonomiese Triniteit. Die filioque het tot gevolg dat die Westerse teologie die Drie-eenheid uit die oog verloor het en die fokus laat val op die aanbidding van God as essensie. Vader, Seun en Heilige Gees word in die tipe van denke agterweë gelaat (Heron 1980:183). Juis hier kom die groot verskil tussen Ortodokse Ooste en Katolieke Weste die duidelikste na vore. Liturgiese ervaring van die waarhede van die Skrif staan sentraal. Doksologie is die eerste taak van die teologie. Die historiese werklikheid van Jesus wat mens geword het, ware mens en ware God, kan nie teoreties deurdink word nie, maar slegs doksologies in die liturgie deurleef word (Watson 1988:317). In die konteks van die liturgie is dit onmoontlik om die Gees los van die Vader of die Seun te sien.

God se openbaring het plaasgevind om die mens te vernuwe en nie sodat die innerlike van God geopenbaar mag word nie. Filioque pretendeer om iets van die inter-Trinitariese verhouding weer te gee in 'n teoretiese konteks los van die liturgie, met ander woorde op so 'n wyse dat dit die skepsel nie aanraak nie (Watson 1988:318). Dit, terwyl dit die doel van die openbaring is om God met mens te verenig, 'n vereniging wat nie bereik word deur teoretiese denke nie, maar deur die meelewing in liturgie (Watson 1988:327). Liturgie moet uiteraard 'n sterk doksologiese karakter dra (LaCugna \& McDonall 1988:191). Hierdie loflied is altyd weer nuut aangesien God dieselfde bly, maar tog tree God altyd weer in die geskiedenis op en hou altyd weer die verhouding met Sy skepsels nuut. Die sterk soteriologiese element wat eie is aan die doksologie moet die skepsel van die Skepper vernuwe. 
Primêre teologie is normatief vir sekondêre teologie. Met ander woorde die liturgie gaan aan die dogmatiek voorskryf hoe en waaroor om na te dink. In die Ortodokse Ooste het die primêre teologie die basiese wyse gebly vir die beoefening van alle teologie. Trouens, daar is somtyds nie verder as die primêre vlak van teologie beweeg nie. In aanbidding word daar geen onderskeid getref tussen 'God' en 'God vir ons' nie (LaCugna \& McDonall 1988:197). Dit is nie werklik vir 'n gelowige moontlik om 'n objektiewe beeld van buite te kry nie. Die begrip van God word bepaal deur 'n geloofsverhouding en hierdie kennis word ontvang deur die werking van die Heilige Gees. Die Heilige Gees is die hermeneutiese sleutel tot die verstaan van God (LaCugna \& McDonall 1988:201). In Reformatoriese terme sou ons kon stel dat die Gees die Skrif ontsluit. Indien daar kwalik tussen God en God vir ons onderskei kan word, ontstaan die vraag onwillekeurig of hier tog nie sprake daarvan is dat die immanente- en die ekonomiese Triniteit naby aan mekaar lê nie.

Die Ortodokse Ooste se klem op die doksologiese het ook 'n ander perspektief. Dit is nie sonder rede dat die Ooste waarsku teen denke wat uit die doksologie van die kerk logiese afleidings oor die wese van God wil maak nie (LaCugna \& McDonall 1988 207). Terwyl die Weste se denke baie wissel tussen immanente- en ekonomiese triniteit, lê die Ooste klem op die ekonomiese triniteit soos in die geskiedenis ervaar. Hierdie geskiedenis vertel nie die logiese verhaal van dit wat in God aangaan nie. Johannes 14:26 en 15:26 stel letterlik dat die Vader die Gees stuur. Dit stel wat in die geskiedenis plaasgevind het. Daar word nie ontken dat die Gees se werk iets met die Seun te doen het nie,en dit staan bo twyfel vas dat die Gees in 'n sekere sin die werk van die Seun voortsit. Om die logiese afleiding te makk dat die Gees deur die Seun uitgestuur word, is om in die loflied tot God iets van die Vader weg te neem en onregmatig aan die Seun toe te ken. Ons het reeds gesien dat die Ooste sterk klem lê op die Drie Persone, en slegs sekondêr die Eenheid raaksien. Waar daar in so raamwerk aanbid word, kan die filioque nie aanvaar word nie.

Van die begin af was die Ortodokse Ooste onverbiddelik in sy standpunt dat die filioque 'n skandelike eensydige byvoeging tot die belydenis is en teologies nie regverdigbaar nie. Indien die filioque egter verwyder word, sal dit 'n dramatiese stap vorentoe wees op die ekumeniese pad na eenheid (Stylianopoulos 1979:23; 1991:275). Eenheid begin met 'n gemeenskaplike belydenis van geloof in die DrieEenheid. Die ganse Kerk is dit eens dat Vader, Seun en Heilige Gees as een God aanbid en verheerlik moet word. Indien daar eenstemmigheid is, is die vraag nou of die filioque nie dalk

- teologiese spekulasie oor die immanente triniteit is;

- 'n alternatiewe interpretasie van die triniteit is; of

* dalk bloot net ketterse leer is nie (Stylianopoulos 1979:24)? 
Die verskil tussen die Seun en die Gees kom onderskeidelik na vore in die woorde 'genereer' en 'uitgaan', wat dui op die oorsprong van Seun en Gees. Die feit dat die woorde 'genereer' en 'uitgaan' gebruik word, dii slegs op die individualieit van Gees en Seun en kan nie verder gevoer word om die aard van die oorsprong op te helder nie. Anders gestel, die twee woorde dui op die eie aard en werk van Gees en Seun en nie op 'n groot onderskeid sover dit die aard van die oorsprong van Seun en Gees betref nie (Stylianopoulos 1979:25). Eienskappe wat deur die keuse van dié woorde aangedui word, moet ten alle koste beskerm word. Elk van die woorde dui op 'n eienskap wat eie is aan slegs daardie Persoon van die Triniteit. Die eienskap van die Vader is dié van ongeborenheid of ewige vaderlikheid, dié van die Seun is generasie of seunskap, en dié van die Gees is prosessie of uitgestuurdheid (Stylianopoulos 1979:25). Alhoewel die drie persone éen is, word hulle net deur hul eie eienskappe van mekaar onderskei. Hulle deel alle gemeenskaplikhede, maar die eiesoortigheid van elk mag nooit verwar word nie. Selfs al is dit so dat Seun en Gees elk van die Vader af kom, funksioneer hul elk afsonderlik. Hierdie onderskeid kan ook slegs getref word na aanleiding van dit wat die Skrif vir ons oor dié se optrede in die geskiedenis sê. Let wel, daar word nie iets gesê oor die immanente Triniteit nie.

Volgens die Ortodokse Ooste is die ware antwoord teen die Ariese dwaalleer dat die aard van die oorsprong van die wêreld radikaal verskil van die aard van die oorsprong van die Gees en die Seun (Stylianopoulos 1979:26). Dit kom daarop neer dat die filioque nie nodig was om die Goddelikheid van Christus te bevestig nie. Christus se oorsprong is totaal anders as die skepping van hemel en aarde. In die konteks van die oorsprong en wese van die Godheid is die filioque onaanvaarbaar. Die enigste konteks waar die filioque aanvaarbaar sou wees, is in die konteks van die wil van God met die mens (Stylianopoulos 1979:28). Daar moet 'n onderskeid getref word tussen die wil van God en die essensie van God. Indien die Weste se standpunt dat die Vader al Sy eienskappe aan die Seun oorgedra het, waar is, beteken dit dat die Gees self ook oorsprong moet wees (Watson 1988:328). Dit plaas jou in 'n ewige sirkel waaruit nie ontsnap kan word nie. Dit is veiliger om te sê dat God die Vader alle eienskappe aan die Seun oorgedra het, uitgesonderd dié van generasie. Dit wil sê slegs die Vader is oorsprong van die Heilige Gees. So gesien is die Vader die oorsprong van die Gees, nie volgens Sy essensie (wat al Drie deel) nie, maar volgens Sy persoon as Vader.

Die sterk klem op die Eenheid van God in die Weste neig al hoe meer na 'n modalisme waarin die afsonderlikheid van die drie Persone verwar word of vervaag. Aan die ander kant neig die Ooste se standpunt na subordianisme en triteïsme (Watson 1988:327). Prakties kom die denke van die Ortodokse Ooste daarop neer 
dat God altyd weer opnuut in die geskiedenis deur Christus in die Gees optree. Die mens se pad na God gaan langs dieselfde weg, naamlik in die Gees deur Christus na God (LaCugna \& McDonall 1988:195). Die hiërargie wat hier ter sprake is, is baie duidelik te sien.

\section{EKUMENIESE STANDPUNT}

Ekumenisme verkondig die evangelie van eenheid. Juis omdat die filioque 'n historiese byvoeging is tot die enigste gemeenskaplike simbool (Niceno- Constantinopolitanum) voor Oos en Wes geskeur het, is dit genoeg rede om dit af te wil skaf (Bray 1983:99). Dit is duidelik 'n standpuAt van 'n organisatoriese eenheid, verwoord deur 'n gemeenskaplike simbool. Dieperliggende teologiese verskille is van minder belang.

Die Ortodokse Ooste en die Weste kan elk 'n beskuldiging teen die ander inbring. So kan die Ooste daarop wys dat dit nie werklik moontlik is om ten volle kontak met die Vader in die Gees te veronderstel terwyl die filioque daar staan nie. As antwoord stel die Weste dat die band tussen Gees en Christus vaag en onbepaald is sonder die filioque. Daar moet tussen hierdie twee uiterstes beweeg word. 'n Model wat gebruik word om die probleem op te los, sal moet rekening hou met die liturgiese behoeftes van die Ooste waar die mens deur die Gees omgaan met die Vader, sonder om uit die oog te verloor dat ons hier met die Gees van Christus te doen het (Ritschl 1979:12).

Veral die Anglikaanse kerk het al baie aan die verwerking van die filioque gedoen juis omdat die ekumeniese belang so hoog op die sakelys is. Die algemene gevoel is dat die filioque gelaat kan word, hiervan is die uitslag van die Moskou konferensie (1976) 'n tekenende voorbeeld. Na gesprek met die Russies-Ortodokse kerk het die Anglikaanse afgevaardigdes eenparig besluit dat die skriftuurlike gronde van so ' $n$ aard is dat die filioque maar gelaat kan word. Tog handhaaf die Anglikaanse kerk die amptelike standpunt dat die filioque nie noodwendig in stryd met die Skrif is nie. Hugh Montefiore (1982:420) gaan in sy benadering uit van die amptelike dokumente van die Angelikaanse kerk, sonder om self na die Skrif te verwys. Daaruit blyk dit dat die Anglikaanse belydenisskrifte en Skrifverstaan geen fout met die insluiting van die filioque vind nie. Die vraag ontstaan nou waarom iets verander moet word wat in ooreenstemming met die Woord van God is. Niks minder as die status van die belydenisskrifte is hier in gedrang nie (Montefiore 1982:420). Die probleem is dat daar in die Skrif met God, soos Hy Homself aan die mens in die geskiedenis openbaar het, omgegaan word. Alhoewel God daardeur as God geken word, is die Skrif nie die een of ander handboek waarin die oorsprong van God of die Gees nagespeur kan word nie. Verder ontbreek die taal om hierdie 
verhouding voldoende te omskryf. Die onderskeid tussen uitgaan en generasie blyk volgens Montefiore ontoereikend om die saak duidelik te stel (Montefiore 1982: 421). Aangesien die saak oop is vir bespreking en daar persone is wat sterk voel vir die behoud van die filioque en ook persone is wat sterk standpunt inneem teen die filioque, blyk die versoenende gebaar te wees om beide te aanvaar. Die langer en korter weergawe van die Niceno-Constantinopolitanum kan aangeneem word in die liturgie van die kerk (Montefiore 1982:422; Every 1979:48). Die vraag moet gestel word of daar 'n houdbare teologie bedryf kan word waar die filioque verwerp en aanvaar word.

Die Lutherane kies ook vir beide gebruike van die Niceno-Constantinopolitanum (Chapman 1991:240). Hierdie standpunt word gemotiveer deur te verwys na die konteks waarbinne teologie bedryf word. In die Ortodokse Ooste is ander sake ter sprake as in die Weste. Die filioque vervul egter 'n belangrike funksie aangesien die teoloog herinner word aan die eenheid van Christologie en Pneumatologie wat steeds as uitdaging geld (Chapman 1991:259). In hierdie benadering is daar sprake van versoening, terwyl daar tog ook erns gemaak word met die teologie waarbinne die filioque geld. In die laaste gedeelte sal daar by hierdie benadering aangesluit word met die gedagte van die filioque as model.

Smolik (1981:219) stel dit in sy artikel dat nie net die ekumeniese debat besinning oor die filioque bewerkstellig nie, maar so ook die 'God is dood' teologie. Opnuut moet denke oor God Drie-enig opgehelder word. Denke oor die Triniteit sal onmiddelik die Gees en die rol van die Gees impliseer. In die Reformatoriese tradisie word daar nie altyd so 'n groot onderskeid tussen die ekonomiese- en die immanente Triniteit veronderstel nie. Dit word gedoen deur te aanvaar dat God nie anders as Sy openbaring is nie. Hierdie openbaring vind ons in die Skrif en juis daarom word die Skrifbewys so hoog in die Refomatoriese tradisie aangeslaan (Smolik 1981:220). Die Skrif moet egter reg hanteer word en juis daarom is dit onregverdig om een teksvers uit te haal en as die finale woord oor 'n saak te aanvaar.

Die verwyt dat Christus as tweede bron aangedui word, het tot gevolg dat die Gees eerder as die arm van Christus gesien word. Hierteenoor sou die Ooste die Gees eerder wou sien as 'n tweede arm van die Vader waarmee Hy die mens na Hom toe trek (Jonker 1981:117). Daar is in 'n sekere sin 'n temporele voorrang wat aan die pneumatologie verleen moet word aangesien die Gees voor die Seun aan die werk was (LaCugna \& McDonall 1988:215). Die keuse van volgorde van loci van die sistematiese teologie is egter van sekondêre belang. Een van die oplossings wat met die eerste aanblik hoogs aanvaarbaar lyk, is om te praat van ex Patre Filii, met ander woorde, van die Vader van die Seun. Dit sal vir die Ooste na 'n aan- 


\section{Dic filioque}

vaarbare oplossing lyk aangesien dit die alleenheid van die Vader ten opsigte van bronwees bevestig (Bray 1983:99), maar is egter nie bevredigend nie in die sin dat dit steeds nie die rol van die Seun ten opsigte van die uitstuur van die Gees reg of ten volle verwoord nie. Die probleem is die volgende. Aan die een kant het ons die Ooste wat die filioque wil afskaf, met die gevolg dat die Gees nie aan die Seun gekoppel word nie. Die Weste aan die ander kant, se benadering koppel die Gees en die Seun, maar in 'n sekere konteks laat dit nie ruimte vir die ander werk van die Gees nie.

Die grootste probleem, sover dit die ekumeniese gesprek oor die verhouding Gees en Seun betref, is volgens Schlink (1985:758) daarin geleè dat daar geen direkte Skrifuitspraak oor die uitgaan van die Gees vanuit die Seun is nie. Tog is daar 'n groot aantal sitate wat aangehaal kan word wat aandui dat daar 'n band tussen Seun en Gees bestaan. Daarby wil Schlink (1985:758) onderskei tussen die aardse Jesus as die ontvanger van die Gees en die verhoogde Jesus as die een wat skenk. Schlink is daarvan oortuig dat nie een van die toelogieë wat tot die filioque aanleiding gegee het, kerkskeurend ingewerk het nie. Die eenheid van die kerk is belangriker as enige spekulatiewe denke oor die filioque. So 'n eenheid word bereik deur geloof in Jesus as Heer en Heiland en geloof in God Drie-Enig.

Die Charismatiese beweging van ons tyd het opnuut die klem laat val op die vernuwende werk van die Heilige Gees. Die vraag wat gestel moet word, is of dit moontlik is om die werking van die Gees in jou diepste wese te ervaar sonder om iets te weet van die versoenende werk van Christus (Bray 1983:103). Is dit moontlik om die werk van die Gees los van die Skrif te ervaar? Kan die Vader geken word deur bemiddeling van die Gees, sonder die Seun of die Skrif? Watter funksie vervul die Gees in so 'n geestelike erediens, in 'n spiritistiese liturgie? Aan die ander kant is die vraag of dit die Gees se enigste funksie is om die mens te oortuig van die versoening in Christus, in 'n proses waar heiliging niks anders is as 'n groeiende verstaan van die regverdiging deur geloof nie? Daar sal waarskynlik opgemerk word dat die charismatiese groepe graag die filioque sou wou afskaf sodat 'die Gees kan waai waar Hy wil', soos $\mathrm{Hy}$ wil, selfs los van die versoening in Christus. Hollenweger (1984:41) lè sterk klem op die pneumatologie van die Ou Testament. Daaruit blyk, volgens hom, dat die werk van die Gees van 'n meer omvattende aard is as wat erken sou wou word. Die verstaan wat die filioque tot gevolg het, maak dat oë en harte gesluit bly vir al die dinge wat die Gees kan bewerk. Juis daarom kan die filioque nie toegelaat word nie. Dit is duidelik dat die filioque slegs speelbal word in die ekumeniese beweging. Daar moet gekies word tussen eenheid aan die een kant en filioque aan die ander kant. 


\section{REFORMATORIESE STANDPUNT}

Verskillende Reformatore kan aangehaal word om die Reformatoriese standpunt duidelik te stel. Een saak staan egter vas, die filioque is integrale deel van die teologie wat Reformatories bedryf word. Tog is dit waar dat die filioque ' $n$ klein gedeelte van die Reformatore se denke beslaan, of selfs glad nie direk behandel word nie (Bray 1983:102). Dit het onder andere daartoe gelei dat daar van die Ortodokse teoloë is wat van mening is dat die filioque slegs ingeglip het by die teologie van die Reformasie, maar dat die Reformatore die filioque kan laat wegval sonder dat daar enige verskil opgemerk sal word. Anders as wat ekumene graag sou wou stel, of as wat die Ortodokse kerk dink, is dit nie net 'n saak wat onnadenkend deur die Reformasie oorgeneem is nie. Die Reformatore het immers die Symbolum Quicumque opgeneem as belydenis. Uit wat volg, sal dit duidelik blyk dat filioque deel van die denke van die Reformasie was en is.

Alhoewel Calvyn nie veel aandag skenk aan die filioque nie, is dit nie moontlik om sy teologie voor te stel sonder die filioque nie. Hy noem die Gees die Gees van Christus (Bray 1983:139; Calvijn 1 xxiii 18-19, III $12-3$ ). Calvyn is daarvan oortuig dat die mens die volheid van God in die Seun kan sien. Hierdie volheid sien die mens deur die Gees. Dit gebeur nie deur die een of ander energie wat die Gees uitstraal nie, maar deur die hupostatiese eenheid wat die Gees met die mens bewerk deur in hom te woon (Bray 1983:141). Die werk van die Gees is om die mens oor te maak na die beeld van Christus, sodat ons die voordele van Christus se verhouding tot die Vader kan geniet. Ons word nie verander ten opsigte van ons natuur na goddelike wesens toe nie, maar opgehef tot die vlak van gemeenskap met die drie Persone van die Triniteit. Die Gees maak ons gelyk aan die hupostasis van die Seun sodat ons deur God aangeneem kan word, wat beteken dat die Gees deur die Seun uitgestuur moet word. Hieruit volg dit logies dat ons die evangelie aangaande Christus aanvaar op grond van die innerlike getuienis van die Gees. Ons ken Christus deur die Gees, omdat die Gees ons hiervan oortuig.

Die verhouding tussen mens en God in Christus is 'n persoonlike verhouding waarin die mens in al die beloftes van God deelagtig word. In hierdie verhouding speel die persoon van die Gees van Christus 'n belangrike rol. Hier kan daar nie sprake wees van ' $n$ natuurlike teologie wat van God as objek praat nie. Die filioque kan kwalik bestaansreg hê in 'n natuurlike teologie waar daar oor allerlei sake gespekuleer word. In 'n teologie waar die Gees die mens persoonlik weer bind aan God, kan dit nie anders as dat die filioque die band sal duidelik maak nie. Christene deel met Christus in die innerlike bestaan van God deur die werking van die Heilige Gees. Die filioque bevestig dié persoonlike verhouding (Bray 1983:141). 
Barth (1963:548) kan hom nie vereenselwig met die Oosterse voorstel dat die Gees van die Vader deur Christus gestuur word nie, aangesien dit die verhouding tussen Seun en Gees op so 'n wyse aantas dat daar nie waarlik van die Gees van Christus gepraat kan word nie. Hierdie eenheidsdenke van Barth bring hom, volgens sy kritici, naby aan 'n modalisme waar hy nie onderskeid kan tref tussen bestaanswyses en die manier waarop God Homself as God openbaar nie (Watson 1988:324). Volgens Smolik (1981:220) stel Barth dat teksverse komplimentêr tot mekaar verstaan moet word en die geheel moet by die beoordeling van 'n saak in ag geneem word. God se verkiesing van die mens speel 'n belangrike rol in die Reformatoriese denke. Die Gees se rol in so 'n verkiesing sal van groot belang wees (Smolik 1981:221). Omdat die Latynse woorde Opera Trinitatis ad extra indivisa sunt (die werk van die Triniteit na buite is onverdeeld) deur die Reformatore aanvaar word, kan daar ' $n$ nouer band tussen werk van Seun en werk van Gees aangedui word. Hoe kan 'n mens in Jesus glo sonder om deur die Gees beweeg te word? Reeds word daar in so konteks opgemerk dat die filioque vanselfsprekend is. Daar is egter die vraag oor die universaliteit van die werking van die Heilige Gees en hoe die werking van die Gees in so konteks ingepas kan word (Smolik 1981:222). Hierdie saak sal beslis aandag moet geniet. Barth se hantering van die saak maak dit duidelik dat hy dit as 'n belangrike deel van die teologie van die Weste gesien het. Sy hantering is meer as wat van die oorgrote meerderheid van die Refomatoriese teoloë gesê kan word (Smolik 1981:222).

Barth (1963:548) neem as beginpunt dat die ekonomiese en immanente Triniteit dieselfde werklikheid is. Dit maak net nie sin dat ons van 'n ander werklikheid aangaande God moet praat, as die werklikheid van God waarmee ons in die openbaring gekonfronteer word nie. Die openbaring moet ernstig opgeneem word as die Selfopenbaring van God en die eerste funksie van die filioque is om aan te dui dat in hierdie openbaring God vir ons is en nie ons vir God nie. Deur die Seun beteken dat die inisiatief van God, ook deur Sy Seun na die mens toe kom. Die mens beweeg nie na God en ontmoet Hom langs die pad nie.

In die tweede instansie is die filioque aanduiding van gemeenskap tussen Vader en Seun. Die Heilige Gees is die liefde, die essensie van die verhouding tussen die twee wyses van bestaan van God (Barth 1963:549). Dit is opmerklik dat die metafoor van Augustinus aktief deur Barth oorgeneem word (Die Een wat Lief het, die Geliefde en die band van Liefde). Hierdie verhouding binne die immanente Triniteit word deur die filioque aangedui na aanleiding van die ervaring van die ekonomiese Triniteit. Barth se fokus op die eenheid van God is duidelik raak te lees en die filioque vervul die rol van verdere bevestiging van hierdie standpunt. Die filioque dui egter ook op die sterk band tussen mens en God, met die mens as daar vir God en God daar vir die mens. Slegs die persoon van die Gees kan dit vermag. 
In die derde instansie stel Barth dit dat indien die Gees slegs van die Vader uitgaan, daar geen objektiewe gronde is vir die mens om gemeenşkap met God te kan hê nie. Feitelik maak dit die openbaring leeg en tydloos (Barth 1963:550). Anders gestel, sonder Christus as middelaar (ware mens en ware God) kan daar geen werklike sprake van kontak tussen God en mens wees nie. Op die praktiese (ekonomiese) vlak stel Barth (1963:550) dat die weglaat van die filioque lei tot die gevolgtrekking dat die enigste kontak tussen God en mens dié van Skepper en skepsel is, en dit gee aanleiding tot 'n naturalistiese en onetiese teologie. Dit maak die weg oop vir 'n mistiese godsdiens. Barth neem Skrifbewys ernstig op en sy beswaar teen die Ooste se klem op slegs Johannes 15:26, blyk duidelik wanneer hy aandui dat die Skrif in geheel in ag geneem moet word en nie fragmentaries aangehaal moet word nie (Barth 1963:549).

Barth (1963:551) spreek hom ook sterk uit teen die gedagte dat daar gepraat kan word van die Gees as van die Vader deur die Seun gestuur. Dit is nie versoenbaar met die gedagte van 'n persoonlike ontmoeting nie aangesien die Vader en die Seun nie twee punte in 'n proses is nie. Die Vader stuur die Seun en die Seun gaan van die Vader uit en hulle is ewig aan mekaar gebind deur die band van liefde, dit is die Heilige Gees. God gaan ook uit tot die skepsel wat van Hom af weggeval het. Deur dieselfde band, naamlik die liefde, trek God die skepsel, die mens, na Hom toe. Versoening is 'n aktiwiteit van die Vader en die Seun. Die mens is die een wat ontvang, die begunstigde. God tree in 'n persoonlike verhouding met die mens. Hierdie persoonlike verhouding is 'n aktiwiteit van God Drie-Enig en dit word deur filioque verwoord.

Moltmann (1981:145) stel dit duidelik dat God aan Homself getrou is. Anders gestel, die verskil tussen ekonomiese- en immanente Triniteit kan nie ernstig opgeneem word nie, God is nie anders as dit wat Hy openbaar het nie, Sy wese verskil nie van dit wat $\mathrm{Hy}$ in die geskiedenis geopenbaar het nie. Die mens kan nie van hierdie God iets anders te sê as dit wat $\mathrm{Hy}$ in die geskiedenis openbaar het nie, aangesien die gevaar altyd bestaan dat die mens met abstraksies (waarin die groot gevaar van kettery lê) besig kan raak (Moltmann 1981:151). God openbaar Homself in tyd en die mens staan midde in tyd, inteendeel die mens is tydgebonde. Die mens kan homself nie eens in sy denke losmaak van tyd nie. Moltmann (1981:145) staan meer krities teenoor die filioque, maar wil dit tog behou aangesien die gevaar van Triteïsme net so gevaarlik is soos Modalisme. Vir Moltmann gaan die Gees baie duidelik uit van die Vader maar dan beslis van die Vader van die Seun. Die verhouding kan soos volg nader omskryf word: Die Gees gaan van die Vader uit, en word deur die Seun ontvang. Dit is tussen hierdie twee pole dat ons die filioque moet interpreteer. Van die Vader gaan die Gees uit en kry so Sy Godelike natuur, 
Sy Goddelike eksistensie. Van die Seun word die Gees ontvang, en kry so sy tydsbestaan. Van die een ontvang Hy Goddelike eksistensie (existenz) en van die ander relasionele gestalte (gestalt). Die twee is nie van mekaar te skei nie, slegs te onderskei (Moltmann 1981:148). Die mens ontmoet die Gees in die tyd, maar weet tog dat dit God is wat hy hier ontmoet. Om uiting te gee aan hierdie dialektiek wat Moltmann in die bestaan van die Gees sien, bedoel hy nie dat die filioque geskrap moet word nie, maar dat die interpretasie van die filioque juis moet wees dat dit die Gees is wat van die Vader van die Seun uitgaan en van die Vader en die Seun Sy gestalte ontvang. Op sy unieke manier interpreteer Moltmann die voorbestaan en voortbestaan van die Gees aan die hand van die verskillende verhoudings in die Triniteit.

\section{FILIOQUE VANDAG}

Uit die voorafgaande is dit duidelik dat Reformatore en die Ekumeniese beweging 'n keuse vir of teen die filioque veronderstel. Die kerk maak wel erns met die belydenisse wat hy aanvaar, maar hierdie band is eerder 'n inhoudelike instemming as wat dit ' $n$ historiese band is. Alhoewel die filioque nie die onderskeid tussen Vader en Seun so duidelik maak nie, is dit nie 'n rede om dit agterweë te laat nie. Augustinus se gedagte dat die Gees primêr van die Vader uitgaan, moet weer bespreek word. Die argument is dat die Vader die Seun gegenereer het van alle ewigheid af en in die proses het $\mathrm{Hy}$ al Sy eienskappe aan die Seun oorgedra, insluitende die vermoë om die Gees uit te stuur. Ofskoon die Gees wel van die Seun uitgaan, gaan Hy primêr van die Vader uit en in afgeleide sin, van die Seun.

Nieteenstaande die feit dat die filioque 'n goeie funksie vervul in die denke oor die Gees se rol in die verlossingswerk van Christus, stel die Ooste dat die filioque nie reg laat geskied aan die werk van die Gees in die skepping nie. Die teendeel is egter die waarheid aangesien God Drie-Enig betrokke was by die skepping, elk van die drie Persone op 'n ander manier. Die doelbewuste koppeling wat Johannes 1:1 met Genesis 1:1 bewerkstellig, maak dit vir ons onmoontlik om die skepping los van die aktiwiteit van die Seun te sien. Daar word in Genesis 1:1 reeds na die Gees van God verwys. Die filioque wil ook nie pretendeer om 'n volledige leer aangaande die Gees te stel nie.

Wanneer ons na die Skrif kyk in 'n poging om te sien of daar nie dalk vandaar lig op die saak gewerp kan word nie, is dit gou duidelik dat met Barth saamgestem moet word dat daar nie net op een teks teruggegryp kan word nie. Die keuse van eksegetiese metode gaan inwerk op die resultaat van die Skrifondersoek. Een saak kom egter baie duidelik na vore, naamlik die onlosmaaklike band tussen die werk van die Gees en die werk van Christus. Enige begrip van die Triniteit sal rekening 
moet hou met hierdie fundamentele band tussen Gees en Christus (Heron 1987: 846). Die nuwere eksegese sal ook baie duidelik inspraak moet hè. Alhoewel aanvaar word dat die laaste woord in terme van eksegese nooit gespreek kan word nie, omrede daar slegs ten dele geken word, kan tentatiewe standpuntinname nie verhinder word nie, hoe voorlopig dit ookal mag wees. Daar moet gewaak word teen die gevare van 'n Modalisme of 'n Christomonisme, gevare waarteen verskeie van Barth se kritici gewaarsku het. Op die spoor van die Reformatore kan 'n poging aangewend word om 'n eie standpunt oor die filioque te formuleer. In hierdie formulering sal die gedagtes van Calvyn, wat tog implisiet teenwoordig is in die denke van Barth, ook 'n plek moet vind.

'n Baie sinvolle riglyn, tydens die hantering van die filioque, is om die gebruik van teologiese taal op te helder. Daar moet in gedagte gehou word dat spreke oor God afgeleide spreke is, met gebruikmaking van taal vol metafore, simbole of modelle. Alhoewel dit met 'n eerste aanblik lyk asof dié terme uitruilbaar is en dieselfde funksie vervul, sal dit by nadere ondersoek blyk dat dit nie die geval is nie. LaCugna en McDonall (1988:203) kies vir modelle as term om teologiese taal te beskryf. Die volgende punte aangaande die model is van besondere belang:

- die model som 'n komplekse verhouding eenvoudig op en skep die raamwerk vir die verstaan van 'n groep probleme wat rondom die model hanteer word. 'n Voorbeeld van so 'n model is die 'creatio ex nihilo' wat 'n model is vir die verstaan van die verhouding tussen God en wêreld;

- 'n model som verhoudings en aktiwiteite op. Die model kan slegs een aspek hanteer of kan meer as een aspek van die openbaring hanteer, met ander woorde 'n breë of smal reikwydte hê;

- 'n model moet altyd metafories verstaan word. Indien die model metafories verstaan word, sal daar groter verdraagsaamheid teenoor ander modelle wees wat anders uitsien. Indien 'n model letterlik verstaan word, het dit tot gevolg dat modelle wat ewe goed gebruik kan word, mekaar uitsluit. Dit is dan verstarde metafore; en

- juis omdat die model metafories gesien moet word, kan dit nie anders as dat die model tentatief slegs voorlopig moet bly nie. Die model is altyd oop (LaCugna \& McDonall 1988:203-205).

In die hantering van die filioque kan dit net voordelig wees om in gedagte te hou dat enige teologiese taal voorlopig van aard is. Deur die filioque as model te hanteer, geskied reg aan die eie aard van die teologie. Dit word moontlik om gesprek met mense te voer wat teen die filioque gekant is. Moltmann se interpretasie is 'n goeie voorbeeld om die filioque as model te hanteer. Sy keuse vir die filioque word 
getemper met sy metaforiese interpretasie van dit wat die filioque verwoord. Die Triniteits- en die Triadologiese model hoef mekaar nie uit te sluit nie, maar kan (indien hulle as modelle vir verstaan gesien word) mekaar aanvul. Dit is wanneer die terme absoluut gebruik word dat in 'n impasse verval word. Die volgende punte moet dien as uitgangspunt in 'n gesprek met voorstanders van 'n ander standpunt oor die filioque:

- die oorsprong van die filioque kan nie ter sake wees wanneer daar gepraat word oor die voortbestaan van die filioque nie. Die saak moet op teologiese vlak beredeneer word;

- die keuse van 'n model van Triniteit sal medebepalend wees vir die interpretasie van die filioque, sonder dat dit beteken dat die filioque net in een model bruikbaar is;

* die filioque moet aan die hand van al die Skrifgegewens geïnterpreteer word; en

- 'n teologie wat die filioque aanvaar, sal rekenskap moet gee van die aktiwiteit van die Gees by byvoorbeeld die skepping.

Vervolgens word die vertrekpunte verder bespreek.

* Indien die oorsprong van die filioque deurslaggewend moes wees vir die bespreking, sou die filioque laat vaar moes word. Die norm waarvolgens bepaal word of 'n belydenis 'n geldige uitspraak gemaak het, is of die betrokke saak die Skrif weerspreek of nie. Die gesag van die besluite van die Algemene Konsilies sal dan uiteraard relatiewe gesag wees (Heron 1987:843). So gesien is die verandering van die teks, soos deur die Algemene Konsilie aanvaar, nie noodwendig verkeerd nie. Aangesien die gesag van die konsilies slegs relatief in die Reformatoriese tradisie is, kan die saak anders benader word. Die belangrikste oorweging sal die teologiese oorweging moet wees. Daarom kan nie volstaan word met ' $n$ liturgiese benadering waar die doksologie die deurslag gee nie. Die ontmoeting met God, die loflied aan Hom kan nie net sonder nadenke herhaal word nie, dit sal later leeg en sonder betekenis wees. Pas die filioque in by die model wat gebruik word om oor die verhouding met God te praat?

* Die Triniteit word eers as een God en dan as drie Persone benader. Die redes hiervoor is veelvuldig. Die persoonlike verhouding tussen God en mens kom beter tot uitdrukking in 'n verhouding waar met die een God omgegaan word. Waar daar kontak is met drie Persone in 'n liturgie wat neig na mistisisme kan daar baie maklik verwarring ontstaan. Godsdiens moet werklikheidsgebonde bly, dit het praktiese implikasies wat baie verder as die liturgie strek, iets wat makliker gebeur in 'n Triniteitsleer as in 'n triadologie. Die streng onderskeid 
tussen immanente- en ekonomiese Triniteit is onbehoorlik. Daar kan net in 'n lewende verhouding met die ware God getree word, nie met 'n mistieke wese wat op 'n manier in die liturgie ontmoet word op so wyse dat vernuwing plaasvind nie. God is nie anders as Sy openbaring nie. Hy is sekerlik meer as Sy openbaring, maar nie anders nie. Enige spreke oor God geskied metafories en is oop vir meer as een interpretasie.

* Die gegewens wat in die Skrif gevind word, wat baie wyer strek as bloot Joh 15:26, ondersteun die koppeling wat filioque bewerk. Die nuwere resultate sal altyd weer bygewerk moet word. Dit wil sê 'n besluit ten gunste van die filioque sal altyd weer oop wees, altyd weer oorweeg moet word. Dieselfde skrifgegewens kan anders in uiteenlopende modelle gebruik word. Solank die terme wat gebruik word as modelle gesien word, sal dit egter steeds moontlik wees om oor die saak gesprek te voer. Binne die Reformatoriese model is die metafoor 'n handige hulpmiddel in die hantering van dit wat in die Skrif raakgelees word.

- Die beswaar dat die filioque nie genoeg sé oor die ander aktiwiteite van die Gees nie, moet as 'n verkeerde begrip van die leer aangaande die Triniteit gesien word. Die filioque wil nie die Gees beperk nie. Deur die filioque word nie ontken dat die Gees betrokke was by die skeppingswerk nie. Inteendeel, vroeër in die Niceno-Constantinopolitanum is daar sprake van die werk van die Gees sonder dat die filioque bygevoeg word. Net soos daar, word geglo dat Christus ook op 'n besondere wyse by die skepping betrokke was, maar dat dit nie in die belydenis verwoord word nie, so is die filioque nie die finale woord aangaande die Triniteit nie, maar afronding van die grense waarbinne daar oor die model van die Triniteit gedink word.

Dit is duidelik dat dit nie nodig is om van die filioque 'n speelbal te maak nie. Ekumeniese gesprek het groter kans op sukses indien die filioque as model hanteer word. Reformatories gesproke is die filioque 'n noodwendigheid, maar dan wel as model. Daar hoef nie finaal vir of teen die filioque gekies te word nie. Die filioque kan as model behou word deur die Reformatore en tegelykertyd kan dieselfde teologiese inhoud van die filioque deur die Ekumene weergegee word sonder om gebruik te maak van die filioque. Dit is 'nie nodig om die twee standpunte reglynig teenoor mekaar te stel nie. Die betoog in hierdie studie was juis om aan te dui dat die een standpunt die ander nie uitsluit nie.

\section{Literatuurverwysings}

Barth, K 1963. Church dogmatics. vertaal deur G T Thomson Edinburgh: Clark Berkhoff, H 1981. Systematic theology. Edinburgh: Banner of Truth Trust. Berthold, G C 1985. Maximus the confessor and the filioque. Studia Patristica $18 / 1,113-117$. 
Bray, G 1983. The filioque clause in history and theology. Tyndale Bulletin 34, 91 144.

Calvijn, J 1983. Institutie. Vertaal deur A Sizoo. Delft: Meinema.

Chapman, M E 1991. A Lutheran proposal for the neuralgic question of the filioque: The L.W.F at Curitaba, Brazil 1990. Joumal of Ecumenical Studies 28/2, 239-259.

Clapsis, E 1982. The filioque question. Patristic and Byzantine Review 1/2, 127-136. Every, E 1979. The filioque question. Sobornost 1/2, $42-49$.

Fahey, M 1979. Son and Spirit: Divergent theologies between Constantinople and the West, in Kung, H (ed), Conflicts about the Holy Spinit, 15-22. New York: Seabury Press.

Heron, A I C 1980. A century of Protestant theology. Cambridge: Butterworth Press.

- The Holy Spirit. Philadelphia: Westminster Press.

- 1987. The Filioque clause: Questions raised by member churches - Attempt at an answer. Reformed World 39/8, 842-852.

Hollenweger, W J 1984. All creatures great and small: Towards a pneumatology of life ,in Martin, D \& Mullen, P (eds), Strange Gifts? Oxford: Basil Blackwell.

Jonker, W D 1981. Die Gees van Christus. Goodwood: NG Kerk Boekhandel.

Kung, H (ed) 1979. Conflicts about the Holy Spirit. New York: Newbury Press.

LaCugna, C M \& McDonall, K 1988. Returning from the far country: Thesis for a contemporary trinitarian theology. Scottish Joumal of Theology 41/2, 191-215.

Moltmann, J 1981. Dogmatische vorschläge zur lösung des filioque-streites, in Vischer, L (ed), Geist Gottes - Geist Christi, (bladsynommers???). Frankfurt: Otto Lembeck.

Montefiore, $H$ 1982. And from the Son? Theology 85, 417-422.

Ritschl, D 1979. The history of the filioque question, in Kung 1979:3-14.

Schlink, E 1985. Okumenische Dogmatik. Göttingen: Vandenhoek \& Ruprecht.

Smolik, J 1981. Filioque in the Reformed tradition. Communio Viatorum 25, 219 222.

Stratoudaki-White, D 1983. Saint Photius and the filioque controversy. Patristic \& Byzantine Review 2/2-3, 246-250.

Stylianopoulos, T 1979. The Orthodox position (on the filioque), in Kung 1979:2330.

Stylianopoulos, T 1991. An ecumenical solution to the filioque question? Joumal of Ecumenical Studies 28/2, 260-280.

Watson, G 1988. The filioque - Opportunity for debate? Scottish Joumal of Theo$\log y 41 / 3,313-330$. 